4. Березкин В. Г., С ах аров В. М., Анв а ер Б. И., Заводск. лаборатория, 32, 669 (1966).

5. K r u p č i k J., L i ška O., S i n g li a r M., Chromatographia, 2, 393 (1969).

6. S chomburg G., Cromatographia, 2, 431 (1969).

7. Kov at s E., Helv. Chim. Acta, 41, 1915 (1958).

8. E t t r e L. S., Analyt. Chem., 36, 31A (1964).

9. Rohrschneider L., Chromatographia, 2, 437 (1969).

$\begin{array}{cc}\text { Институт химии } & \text { Поступила в редакцию } \\ \text { Академии наук Эстонской ССР } & 8 / \mathrm{X} 1970\end{array}$

EESTI NSV TEADUSTE AKADEEMIA TOIMETISED. 20. KOIDE

KEEMIA * GEOLOOGIA. 1971, NR. 1

ИЗВЕСТИЯ АКАДЕМИИ НАУК ЭСТОНСКОЙ ССР. ТОМ 20

Химия * ГЕОЛОГИя. 1971, № 1

удК $541.12 .034 .0^{\circ}$

О. ЭИЗЕН, ХЕЛЬЮ РАУДЕ, РЕЕТ ВННРЕС, Х. КНППЕР

\title{
ИЗУЧЕНИЕ СОСТАВА ЛЕТУЧИХ КОМПОНЕНТОВ РЯБИНОВОГО ВИНА МЕТОДОМ ГАЗОВОЙ ХРОМАТОГРАФИИ
}

O. EISEN, HELJU RAUDE, REET VIIRES, H. KIPPER. PIHLAKAMARJAVEINIS SISALDUVATE LENDUVATE UHENDITE KOOSTISE UURIMINE GAASIKROMATOGRAAFILISEL MEETODIL.

O. EISEN, HELJU RAUDE, REET VIIRES, H. KIPPER. INVESTIGATION OF THE COMPOSITION OF THE VOLATILE COMPOUNDS OF ASHBERRY WINE BY GAS CHROMATOGRAPHY

Объектом данного исследования служили рябиновые вина Валгаского винного завода разной выдержки, изготовленные в 1967 и 1969 гг. Анализировались четыре пробы вина: 1967 г., 1969 г., 1969 г., выдержанное при $50-54^{\circ} \mathrm{C}$ в течение месяца с аэрацией, и 1969 г., выдержанное при $50-54^{\circ}$ в течение месяца без аэрации.

Пробы экстрагировались в делительной воронке смесью пентана с диэтиловым эфиром $(9: 1)$ ['] или только диэтиловым эфиром. После отгонки основной части растворителей экстракты подвергались газохроматографическому анализу на аппарате «Хром-3», снабженном пламенно-ионизационным детектором. Для газохроматографического анализа использовалась колонка из медной трубки длиной $6 \mu$ и внутренним диаметром 4 мм, заполненная полиэтиленгликолем 4000 (15\%) на хромосорбе $W$ 60-80 меш. Газом-носителем служил азот со скоростью $25 \mathrm{~cm}^{3} /$ мин. Температура колонки $85^{\circ}$. Результаты анализа приведены в табл. 1 н 2. 


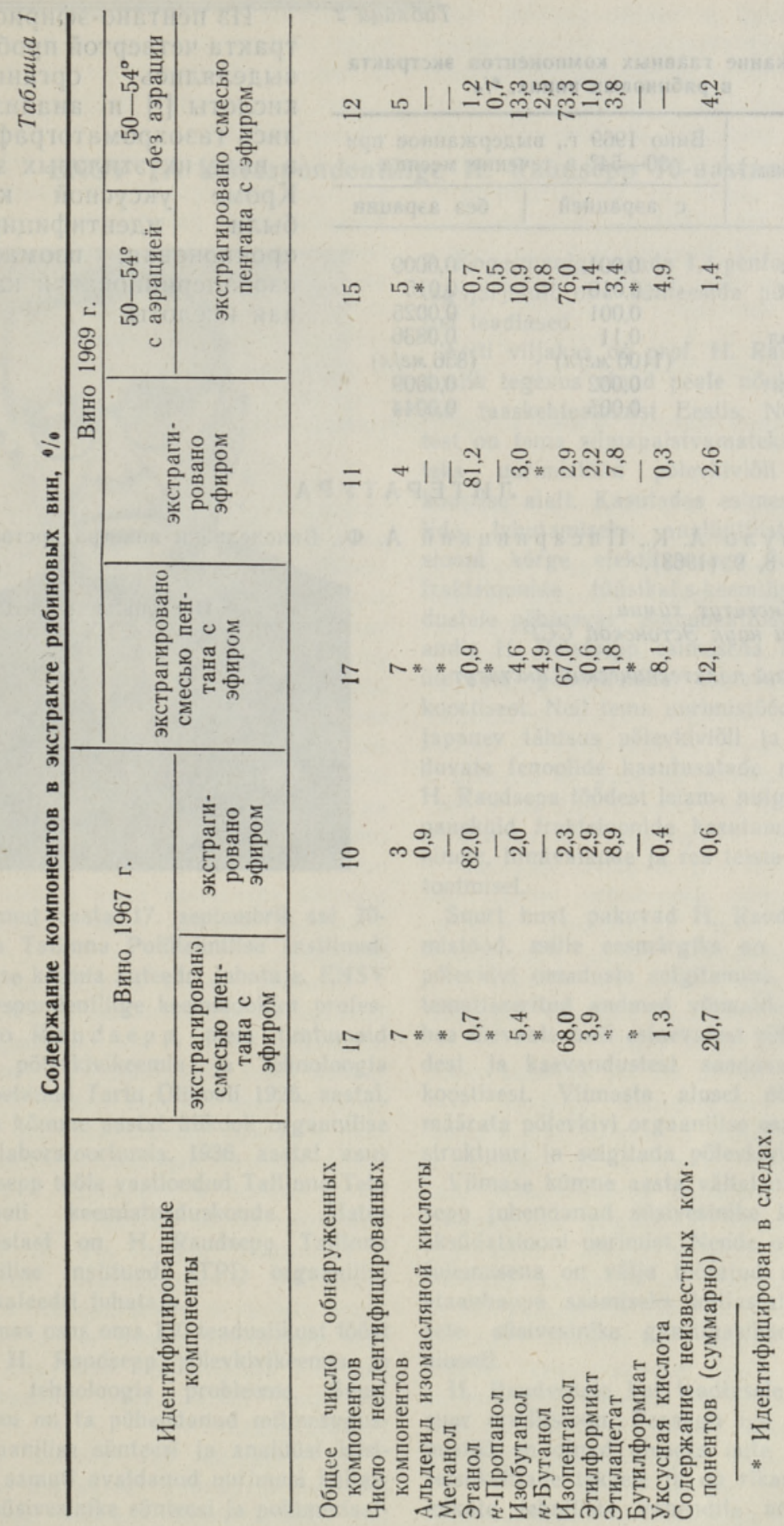


Таблица 2 Из пентано-эфирного экс-

Содержание главных компонентов экстракта в рябиновых винах, \% тракта четвертой пробы вина выделялись органические кислоты [1] и анализирова-

Вино 1969 г., выдержанное при лись газохроматографически

\begin{tabular}{c|c|c}
\hline \multirow{3}{*}{ Компонент } & $\begin{array}{c}\text { Вино } 1969 \text { г., выдержанное при } \\
50-54^{\circ}\end{array}$ \\
& в течение месяца \\
\cline { 2 - 3 } & с аэрацией & без аэрации \\
\hline
\end{tabular}
в виде их этиловых эфиров. Кроме уксусной кислоты были идентифицированы н-Пропанол Изобутанол н-Бутанол

Изопентанол

Этилформиат

Этилацетат

$\begin{array}{cc}0,001 & 0,0009 \\ 0,016 & 0,015 \\ 0,001 & 0,0025 \\ 0,11 & 0,0836 \\ (1100 \mu 2 / \Omega) & (836 \mu 2 / \Omega) \\ 0,002 & 0,0009 \\ 0,005 & 0,0044\end{array}$
пропионовая, изомасляная, изовалериановая и капроновая кислоты.

\section{ЛИТЕРАТ У Р А}

1. Родопуло А. К., Пи сарнициий А. Ф., Виноделие и виноградарство СССР, № 8,9 (1963).

Институт химии
Академии наук Эстонской ССР

Поступила в редакцию $23 / \mathrm{X} 1970$

таллинский политехнический институт 